Abstracta Iranica Abstracta Iranica

Revue bibliographique pour le domaine irano-aryen

Volume 27 | 2006

Comptes rendus des publications de 2004

\title{
« Ideology and Pragmatism in Iran's Foreign Policy ». Middle East Journal, volume 58, (2004), pp. 549-559.
}

Anicée Van Engeland-Nourai

\section{(2) OpenEdition \\ 1 Journals}

Édition électronique

URL : http://journals.openedition.org/abstractairanica/6631

DOI : 10.4000/abstractairanica.6631

ISSN : 1961-960X

Éditeur :

CNRS (UMR 7528 Mondes iraniens et indiens), Éditions de l'IFRI

\section{Édition imprimée}

Date de publication : 15 mai 2006

ISSN : 0240-8910

\section{Référence électronique}

Anicée Van Engeland-Nourai, « « Ideology and Pragmatism in Iran's Foreign Policy ». Middle East Journal, volume 58, (2004), pp. 549-559. », Abstracta Iranica [En ligne], Volume 27 | 2006, document 363, mis en ligne le 02 janvier 2007, consulté le 10 décembre 2020. URL : http://

journals.openedition.org/abstractairanica/6631; DOI : https://doi.org/10.4000/abstractairanica.6631

Ce document a été généré automatiquement le 10 décembre 2020.

Tous droits réservés 


\title{
«Ideology and Pragmatism in Iran's Foreign Policy ». Middle East Journal, volume 58, (2004), pp. 549-559.
}

\author{
Anicée Van Engeland-Nourai
}

1 La tension entre l'idéologie religieuse et le pragmatisme a toujours été présente à travers l'histoire de l'Iran : telle est la thèse de l'article. La Révolution de 1979 n'a fait qu'exacerber ce paramètre. Selon l'A., Cyrus le Grand cherchait déjà un équilibre entre ces deux notions pour maintenir la paix à travers l'empire, bien que le pragmatisme l'emportât à l'époque. L'A. continue ensuite en analysant l'époque des Sassanides plus enclins que les Achéménides à infuser de l'idéologie dans leur politique étrangère. L'histoire iranienne est ainsi couverte et analysée selon ce paradigme pragmatismeidéologie. Ainsi la nationalisation du pétrole en 1953 n'était pas seulement pragmatique mais aussi le résultat de la foi de Mossadegh dans la démocratie sociale.

2 L'article prend l'exemple des relations Iran/Etats-Unis pour illustrer sa théorie. L'A. explique ainsi que si les débuts de la République islamique en politique étrangère ont été teintés d'idéologie, le pragmatisme a toujours été un élément important - ainsi l'achat d'armes de guerre auprès des Etats-Unis.

3 Il estime aussi que la maturation culturelle du pays a fait pencher la balance vers le pragmatisme et le calcul des intérêts de l'Etat aux dépens de l'idéologie religieuse. Il estime que ce mouvement se remarque particulièrement en matière de politique étrangère sous l'administration Khatami. Ce type d'équilibre à la Khatami entre pragmatisme et idéologie est encouragé car il rencontre un grand succès. 
INDEX

Thèmes : 13.1. Iran

\section{AUTEURS}

ANICÉE VAN ENGELAND-NOURAI

Paris 